\title{
BARONESS CHARLOTTA CASTELLI GLEMBAY - WAS SHE HYPERSEXUAL?
}

\author{
BARUNICA CHARLOTTA CASTELLI \\ GLEMBAY - JE LI ONA BILA HIPERSEKSUALNA?
}

\author{
Goran Arbanas*
}

\begin{abstract}
SuMMARY
Hypersexuality disorder (or sexual addiction or excessive sexual drive or compulsive sexual behaviour disorder) is a controversial condition that is present in the International Classification of Disease but not in the Diagnostic and Statistical Manual for Mental Disorders. It is defined as a clinical syndrome characterised by a persistent pattern of failure to control intense, repetitive sexual impulses or urges resulting in repetitive sexual behaviour. The condition is more prevalent in men than in women.

Some medical conditions were described in fictional literature before their formal recognition in medicine, like Huntington disease, Pickwick syndrome, and Munchausen syndrome.

The aim of this article is to analyse the fictional character of Charlotta Castelli Glembay from Miroslav Krleža's play Messrs Glembays from 1928. Krleža presented a woman with a sexual drive that could be described as uncontrollable, organic (physical) in origin, and different from love and affection (that she also experienced, but only with one particular man). The author gave a special name for her condition-erotic intelligence. This sexual behaviour has distressing and devastating consequences. This paper will argue that the play depicts hypersexuality disorder in a woman, with a designation of its aetiology. In concordance with the prevailing attitudes of the time (the early $20^{\text {th }}$ century), hypersexuality in women had negative attributions.
\end{abstract}

Keywords: hypersexuality, sexual addiction, out-of-control sexual behaviour, nymphomania, compulsive sexual behaviour disorder, Miroslav Krleža, Messrs Glembay

Correspondence Address: Goran Arbanas, University Psychiatric Hospital Vrapče, Bolnička cesta 32, 10000 Zagreb, Croatia. E-mail: goran.arbanas@ka.t-com.hr, ORCID ID: http://orcid. org/0000-0002-2770-0942. 


\section{INTRODUCTION}

Medical conditions and diseases have been depicted in fictional literature, movies but also in fine arts. The accuracy of descriptions of symptoms and syndromes depends on the background medical knowledge of the author, their observational abilities, the artistic importance of the character's disease, and the aims and impact the author wants to produce in the reader (observer). It is also possible that the incorporation of medical conditions and syndromes is not necessarily the author's conscious action. ${ }^{1}$ The author can use medical conditions to present their characters better or develop a plot or give a message to the readership, or structure a literary text. ${ }^{2}$ This is known as a literary function of fictionalised medicine. ${ }^{3}$ There are many examples of the usage of literary descriptions of illnesses for literary aims, and Dostoevsky points out that descriptions encountered in literature do not exist in real life but are almost more real than reality itself. ${ }^{4}$

The aim of this article is to present a case of hypersexuality in Croatian literature that was described even before this condition was recognised by medical professionals as a mental/sexual health condition. Krleža's Messrs Glembay have been analysed from many different perspectives: literal, sociological, psychoanalytical, and even vampirical, and this is an addition to the analysis of the play from sexological aspects. ${ }^{5}$

\section{HyPERSEXUALITY}

Hypersexuality (or sexual addiction or compulsive sexual behaviour disorder) is a controversial issue in contemporary sexology, as some authors consider it a medical diagnosis (and a disorder), while others are of the opinion that it is a normal variant of human sexuality. ${ }^{6}$ For that reason, it exists in one of the two contemporary classification systems (International classification of disease /ICD/: it was named excessive sexual drive in ICD-Io, and it is termed compulsive sexual behaviour disorder in ICD-II), whereas it does

\footnotetext{
1 Slunjski, Kristina (2015), Alica u Zemlji Čudesa kao susretište književnosti i medicine i kao poticaj medicinskom nazivlju, Libri \& Liberi, 4 (2), 341.

2 Voss, Hendrik (2012), The representation of movement disorders in fictional literature, Journal of Neurology, Neurosurgery and Psychiatry, 83, 994.

Ibid., p. 994.

Dostoevsky, Fyodor M. (1992). The Idiot, Oxford \& New York; Oxford University Press, 485. Gjurgjan, Ljiljana I. (2003), Fetišizam, vampirizam i pogled drugoga u drami Gospoda Glembajevi Miroslava Krleže, Dani hrvatskoga kazališta: Građa i rasprave o hrvatskoj književnosti i kazalištu, 29 (2), 55.

6 Kingston, Drew A. (2018), Hypersexuality: fact or fiction? Journal of Sexual Medicine, 15, 613.
} 
not exist in another (Diagnostic and statistical manual for mental disorders - DSM), not even among the category of conditions for future study. ${ }^{7,8,9}$ Regarding DSM, it should be added that hypersexuality was present in DSM-III as one of the psychosexual disorders not otherwise classified, and in DSMIII-R as a nonparaphilic sexual addiction. ${ }^{10}$

The controversy regarding hypersexuality covers almost every aspect of this diagnosis. Firstly, there are dozens of names used for the same condition: hypersexuality, sexual addiction, sexual compulsivity, sexual impulsivity, out-of-control sexual behaviour, or nonparaphilic excessive hypersexual behaviour. ${ }^{11,12,13}$ When used to describe hypersexuality in women, it was sometimes named nymphomania (this term was even in use in ICD-Io), and less often hysteromania. ${ }^{14}$ This myriad of terms reflects the authors' different views on the aetiology of the condition. ${ }^{15,16}$ Some authors consider hypersexuality a disorder of sexual desire and therefore classify it among sexual dysfunctions (this was the case in ICD-IO). ${ }^{17,18}$ Others think it is a type of behavioural addiction (and classify it among other addictions, with pathological gambling, for example). ${ }^{19}$ Yet others view hypersexuality as a part of the obsessive-compulsive spectrum (but this view is the least probable as new research has shown that there is a very weak connection between compulsivity

7 The ICD-10 classification of mental and behavioural disorders: clinical descriptions and diagnostic guidelines, World Health Organization (1992), Geneve: World Health Organization.

8 Diagnostic and statistical manual of mental disorders, fifth edition American Psychiatric Association (2013), Arlington: American Psychiatric Association.

9 6C72 Compulsive sexual behaviour disorder (2020), in: World health organization, International classification of diseases, https://icd.who.int/browse11/1-m/en\#/http://id.who.int/icd/entity/1630268048

10 Diagnostic and statistical manual of mental disorders, 3rd edition revisedAmerican Psychiatric Association (1987), Arlington: American Psychiatric Association.

11 Bancroft, John, Vukadinovic, Zoran, (2004), Sexual addiction, sexual compulsivity, sexual impulsivity, or what? Toward a theoretical model, Journal of Sex Research, 43 (3), 225.

12 Garcisa, Frederico D., Thibaut, Florence (2010), Sexual addictions, American Journal of Drug and Alcohol Abuse, 36 (5), 254.

13 Kafka, Martin P. (2010a), What is sexual addiction? A response to Stephen Levine, Journal of Sexual and Marital Therapy, 36, 276.

14 World Health Organization (1992).

15 Levine, Stephen B. (2010), What is sexual addiction?, Journal of Sex and Marital Therapy, 36, 261.

16 Karila, Laurent, Wery, Aline, Weinstein, Aviv, Cottencin, Olivier, Petit, Aymeric, Reynaud, Michel, Billieux, Joel (2014), Sexual addiction or hypersexual disorder: different terms for the same problem? A review of the literature, Current Pharmaceutical Design, 20 (25), 4012.

17 Kafka, Martin P. (2010b), Hypersexual disorder: a proposed diagnosis for DSM-V, Archives of Sexual Behavior, 39 (2), 377.

18 Carvalho, Joana, Stulhofer, Aleksandar, Vieira, Armando L., Jurin, Tanja, (2015), Hypersexuality and high sexual desire: exploring the structure of problematic sexuality, Journal of Sexual Medicine, 12, 1356.

19 Holden, Constance, (2001), Behavioral addictions: do they exist?, Science, 294, 980. 
and hypersexuality). ${ }^{20,21}$ And, finally, there are authors that conceptualise hypersexuality as one of the impulse control spectrum disorders (some research confirms the correlation between impulsivity and hypersexuality). ${ }^{22}$ Today, in ICD-II compulsive sexual behaviour disorder is classified among impulse control disorders. ${ }^{23}$

There is less controversy on the prevalence of the condition, and most of the research shows a prevalence of 3-15\%, with men being hypersexual three to six times as often as women. ${ }^{24,25,26}$

If we agree that hypersexuality (sexual addiction or compulsive sexual behaviour disorder) is a mental/sexual disorder, we can use the definition from ICD-II: a persistent pattern of failure to control intense, repetitive sexual impulses or urges resulting in repetitive sexual behaviour. ${ }^{27}$

The proposed criteria for hypersexual disorder are presented in Table I and a description of symptoms in Table $2.28,29,30$ The main aspect of clinical presentation are sexual urges, fantasies, and behaviours that consume a great deal of time, and are repetitive and difficult to control. There were some suggestions to subclassify the condition in terms of the most prevalent type of sexual behaviour that a person engages in (e.g. masturbation, pornography, sexual behaviour with consenting adults, cybersex, telephone sex, attending striptease clubs). ${ }^{31,32,33} \mathrm{Up}$ to $70 \%$ of patients with this condition reported wi-

20 Womack, Stephani, Hook, Joshua, Ramos, Marciana, Davis, Don, Penberthy, Kim (2013), Measuring hypersexual behaviour, Sexual addiction \& compulsivity, Journal of Treatment and Prevention, 20 (1-2), 65.

21 Bothe, Beata, Toth-Kiraly, Istvan, Potenza, Mark, Griffiths, Mark, Orosz, Gabor, Demetrovics, Zsolt (2018), Revisiting the role of impulsivity and compulsivity in problematic sexual behaviours, Journal of Sex Research, 18, 1.

22 Mick, Thomas M., Hollander, Eric (2006), Impulsive-compulsive sexual behaviour, CNS Spectrums, 11 (12), 944.

23 World health organization (2020).

24 Karila, L. et al. (2014).

25 Seegers, Jennifer A. (2003), The prevalence of sexual addiction symptoms on the college campus, Sexual Addiction \& Compulsivity, 10, 247.

26 Langstrom, Niklas, Hanson, Karl R. (2006), High rates of sexual behaviour is the general populations: correlates and predictors, Archives of Sexual Behavior, 35 (1), 37.

World health organization (2020).

Ibid.

Karila, L. et al. (2014).

Stein, Dan J. (2008), Classifying hypersexual disorders: compulsive, impulsive, and addictive models, The Psychiatric Clinics of North America, 31 (4), 587.

Kafka, M. (2010b), p. 377.

Stein, D. J. (2008), p. 587.

Arbanas, Goran (2011), Seksualna ovisnost, Alcoholism, 47, 285. 
thdrawal symptoms when not engaging in the behaviour: nervousness, insomnia, sweating, nausea, tachycardia, shortness of breath, tiredness. ${ }^{34,35}$

It is important to distinguish hypersexuality from obsessive-compulsive disorder (sexual themes are prevalent among patients with intrusive thoughts but are ego-dystonic), paraphilias (there is also the possibility of comorbidity with paraphilias), and illegal sexual behaviour that is not out-of-control. ${ }^{36}$

The controversy about the condition extends to the treatment, as there is no single agreed-upon mode of treatment (case reports show the usefulness of citalopram, fluoxetine, sertraline, clomipramine, nefazodone, naltrexone, valproate, topiramate, as well as cognitive-behavioural psychotherapy and partner therapy). ${ }^{37,38,39,40,41}$

Table I. The proposed criteria for hypersexual disorder

\begin{tabular}{|c|l|}
\hline A. & $\begin{array}{l}\text { Over a period of at least } 6 \text { months, recurrent and intense sexual fan- } \\
\text { tasies, sexual urges, and sexual behaviour in association with four or } \\
\text { more of the following five criteria: }\end{array}$ \\
\hline Ar.. & $\begin{array}{l}\text { a great deal of time is consumed by sexual fantasies and urges and by } \\
\text { planning for and engaging in sexual behaviour }\end{array}$ \\
\hline A $_{2}$. & $\begin{array}{l}\text { repetitively engaging in these sexual fantasies, urges, and behaviours } \\
\text { in response to dysphoric mood states (e.g. anxiety, depression, bore- } \\
\text { dom, irritability) }\end{array}$ \\
\hline A $_{3}$ & $\begin{array}{l}\text { repetitively engaging in sexual fantasies, urges, and behaviours in } \\
\text { response to stressful life events }\end{array}$ \\
\hline A $_{4} \cdot$ & $\begin{array}{l}\text { repetitive but unsuccessful efforts to control or significantly reduce } \\
\text { these sexual fantasies, urges, and behaviours }\end{array}$ \\
\hline A $_{5}$. & $\begin{array}{l}\text { repetitively engaging in sexual behaviour while disregarding the risk } \\
\text { for physical or emotional harm to self or others. }\end{array}$ \\
\hline
\end{tabular}

$34 \quad$ Karila, L. et al. (2014), p. 4012.

35 Carnes, Patrick, Schneider, Jennifer P. (2000), Recognition and management of addictive sexual disorders: a guide for the primary care clinician, Lippincotts Primary Care Practice, 4 (3), 302.

36 Diagnostic and statistical manual of mental disorders, fifth edition (2013).

37 Kafka, Martin P., Prentky, Robert, (1992), Fluoxetine treatment of nonparaphilic sexual addictions and paraphilias in men, Journal of Clinical Psychiatry, 53 (10), 351.

38 Bostwick, Michael, Bucci, Jeffrey A. (2008), Internet sex addiction treated with naltrexone, Mayo Clinic Proceedings, 83 (2), 226.

39 Khazaal, Yasser, Zullino, Daniele F, (2006), Topiramate in the treatment of compulsive sexual behaviour: case report, BMC Psychiatry, 6, 22.

40 Orzack, Maressa H., Voluse, Andrew C., Wolf, David, Hennen, John (2006), An ongoing study of group treatment for men involved in problematic Internet-enabled sexual behaviour, $\mathrm{Cy}$ berpsychology \& Behavior, 9 (3), 348.

41 Young, Kimberly S. (2007), Cognitive behaviour therapy with Internet addicts: treatment outcomes and implications, Cyberpsychology \& Behaviour, 10 (5), 671. 


\begin{tabular}{|c|l|}
\hline B. & $\begin{array}{l}\text { There is clinically significant personal distress or impairment in so- } \\
\text { cial, occupational, or other important areas of functioning associated } \\
\text { with the frequency and intensity of these sexual fantasies, urges, and } \\
\text { behaviours. }\end{array}$ \\
\hline C. & $\begin{array}{l}\text { These sexual fantasies, urges, and behaviours are not due to the dire- } \\
\text { ct physiological effect of an exogenous substance (e.g., a drug of abuse } \\
\text { or a medication) or a manic episode. }\end{array}$ \\
\hline D. & Person is at least 18 years of age. \\
\hline
\end{tabular}

Table 2. Symptoms of compulsive sexual behaviour disorder in ICD-II

Symptoms may include repetitive sexual activities becoming a central focus of the person's life to the point of neglecting health and personal care or other interest, activities and responsibilities; numerous unsuccessful efforts to significantly reduce repetitive sexual behaviour; and continued repetitive sexual behaviour despite adverse consequences or deriving little or no satisfaction from it. The pattern of failure to control intense sexual impulses or urges and resulting repetitive sexual behaviour is manifested over an extended period of time (e.g. six months or more), and causes marked distress or significant impairment in personal, family, social, educational, occupational, or other important areas of functioning. Distress that is entirely related to moral judgments and disapproval about sexual impulses, urges, or behaviours is not sufficient to meet this requirement.

\section{MedicAl conditions in FictionAl Literature}

Some medical conditions were described in fictional literature before they were recognized and described by medical professionals. Charlotte Brontë, for example, described a person with symptoms that were later recognized by the medical profession as symptoms of Huntington chorea (Bertha Mason, the woman in the attic in Jane Eyre). ${ }^{42,43}$ Jane Eyre was first published in 1847 , while Huntington's disease was described (and later named after) by George Huntington, $\mathrm{MD}$, in $1872 .{ }^{44}$ After Huntington's disease was recognized by the medical profession, there were several descriptions of it in fictional literature

42 Coon, Elizabeth A., Hassan, Anhar (2015), Did the „Woman in the attic“ in Jane Eyre have Huntington disease?, Tremor \& Other Hyperkinetic Movements, 21 (5), 323.

43 Bronte, Charlotte (1847). Jane Eyre, New York; Black \& White Classics.

44 Huntington, George (1872), On chorea, The Medical and Surgical Reporter, 26, 317. 
where the disorder was used for the development of the plot, for example, in Vonnegut's Galapagos, Sawyer's Frameshift and McEwan's Saturday. 45,46, 47, 48

The syndrome characterized with micropsia, macropsia, and disfiguration of perception of own body and external objects was described by Lewis Carroll in his fictional story Alice's Adventures in Wonderland, and was later named the syndrome of Alice in Wonderland.49,50,51 There are some authors who believe that Carroll himself had developmental stuttering and migraines and that he himself had some of these symptoms, either due to migraines or due to taking hallucinogens. ${ }^{52}$ Pickwick syndrome and Munchausen syndrome are other examples of such a practice.

Medical descriptions of characters in fictional literature can be used in the education of future physicians. By reading and commenting about these characters, students can be taught about psychopathology, professional values, professional knowledge, the relationship between a doctor and a patient. ${ }^{53,54,55,56,57}$ Authors who are medical doctors (such as Sir Arthur Conan Doyle or Michael Crichton) can additionally give us an insider view that makes a story more authentic. ${ }^{58}$

\section{Miroslav Krleža: Messrs Glembay}

The main theme of the play is the inner struggle of the main character, Leone, and his relationship with his father (and also his mother and stepmot-

\footnotetext{
45 Vonnegut, Kurt (1985). Galapagos, New York; Delacorte Press/Seymour Lawrence, 83.

46 Sawyer, Robert J. (1997). Frameshift, New York; Tom Doherty Associates, 99.

47 McEwan, Ian (2005). Saturday, London; Vintage.

48 Voss, H. (2012), 994.

49 Carroll, Lewis, (1998). Alice's Adventures in Wonderland, London; Penguin Classics.

50 Andrew, Larner (2005), The neurology of Alice, Advances in Clinical Neuroscience and Rehabilitation, 4 (6), 35.

51 Weissenstein, Anne, Luchter, Elisabeth, Bittmann, Stefan M.A. (2014), Alice in Wonderland syndrome: a rare neurological manifestation with microscopy in a 6-year-old child, Journal of Paediatric Neurosciences, 9 (3), 303.

52 Slunjski, K. (2015), 341.

53 Charpy, Jean-Pierre (2014), Medical thrillers: doctored fiction for future doctors?, Journal of Medical Humanities, 35, 423.

54 Jukić, Vlado, Brečić, Petrana, Savić, Aleksandar (2010), Movies in education of psychiatry residents, Psychiatria Danubina, 22 (2), 304.

55 Haan, Joost, Koehler, Peter J. (2014), Traces of hysteria in novels, Frontiers in Neurology \& Neurosciences, 35, 99.

56 Maxwell, Marilyn (2011), A study in contrasts: inscriptions of posttraumatic stress disorder (PTSD) in two works of fiction, Work, 38, 19.

57 Arbanas, Goran, Kreho, Dinko (2019), Leone Glembay - psihijatrijska i forenzička razmatranja književnog lika, Liječnički vjesnik, 141, 40.

58 Charpy, J.-P. (2014), 423.
} 
her). Nevertheless, the sexuality of one of the main female characters (Charlotta Castelli Glembay) is described in detail. ${ }^{59}$ In contrast to other characters with hypersexuality depicted in literature, here the author gives her explanation of the cause (organic/physical inadequacy), which was not in concordance with other authors at the beginning of the zoth century, who were influenced by Freud's psychological approach to mental disorders.

Miroslav Krleža is the most important Croatian author of the 2oth century. He was a poet, and author of many plays, novels, short stories and essays. ${ }^{60}$ He was a friend of the Yugoslav president Tito and was influential in Croatian literature and political life after the Second World War. ${ }^{61}$

His play Messrs. Glembays. A drama in Three Acts from the Life of One Agremerian Patrician Family is a genealogy ${ }^{62}$ depicting the decay and destruction of the rich (fictional) Croatian family Glembay. The play is set in Zagreb, Croatia, in $1913 .{ }^{63}$ The main male character Leone is a well-known painter who comes back to Zagreb, for a family reunion, after in years.

Leone is the only remaining child of his parents, as both his brother and sister committed suicide. His older brother is said to die after an accident (Leone is convinced it was not an accident but a suicide), and his brother's widow became a nun and went to Asia. She has returned home for the family reunion, too. Leone's sister Alice committed suicide when she found that her boyfriend was in a sexual relationship with her (and Leone's) stepmother. Leone's mother had also committed suicide.

The climax of the play is the discussion between Leone and his father. Leone tells his father that his wife (Leone's stepmother) is a prostitute, that she has been seeing several lovers (one priest, one infantry officer) and that she has had many other lovers, including even him, Leone. After that information, Leone's father dies of a heart attack. In the final act, Leone's stepmother, Charlotta, wants to explain to Leone that she is not as evil and bad as he thinks of her. However, after finding out that her husband had falsified her signature and robbed her of all her money, she loses her temper, and Leone and she start to quarrel, and finally, he kills her with scissors.

\footnotetext{
59 Krleža, Miroslav (2001). Gospoda Glembajevi, Zagreb; Naklada Ljevak.

60 Lukašević, Tatjana S. (2013), Samostanske drame i Glembajevi, Croatica Slavica Iadertina, 9 (2), 433.

61 Novak, Slobodan P. (2004), Povijest hrvatske književnosti, Split; Marijan tisak.

62 Genealogy in literature appears in the second half of the $19^{\text {th }}$ century and depicts several generations of the same family, analysing the destruction of the family. It started with Emile Zola in 1870 .

63 Krleža, M. (2001).
} 


\section{BARONESS CHARLOTTA CASTELLI GLEMBAY: AN EROTIC INTELLIGENCE ${ }^{64}$}

Baroness Charlotta Castelli Glembay is a woman who has had many lovers in her life. In one moment of bitterness, Leone says that the room they are in is not big enough to hold all the men she has slept with. ${ }^{65}$ We know that she was in sexual relations with the priest Silberbrandt, with her stepdaughter's fiancé, with a man who was working in her charity (and who committed suicide and left a beautiful poem describing his love with the baroness), an officer Ballocsanszky, an infantry officer Radky, a judicial apprentice Holleschegg, during a time span of 16 years. The reader finds out about this, not from baroness Charlotta herself, but from Leone, who brings this issue first in a verbal duel with Silberbrandt and later with his father.

When talking to Silberbrandt, Leone said: "Your highly gracious president, baroness Castelli-Glembay was in intimate relationships with this 22-year-old Skomrak!". ${ }^{66} \mathrm{He}$ told his father: "I slept five nights under this roof, and of these five nights, your baroness spent two in Silberbrandt's room!" ${ }^{\prime 7}$ and continued that his sister Alice committed suicide because she "concluded that young Zygmutowicz was sleeping with the baroness! Alice was innocently in love with the young Zygmuntowicz!" ${ }^{68}$ Leone asked his father: "Do you think that that idiotic Oberleutnant Ballocsanszky comes to this house to play bridge with you or because - baroness managed to charm him too?" ${ }^{69}$ When remembering his return home 16 years ago, he mentions:

"chevalier de l'honneur de la baronne uncertain de Radkay, lieutenant - colonel de la Cavalerie Imperiale. And there was also some Gerichtsadjunkt, I think his name was Holleschegg, if I am not wrong. He was a counterpart to these days' Oberleutnant von Ballocsanszky! All of these gentlemen were charmed by the gracious baroness.... Among all of these gentlemen, that summer, the lady managed to charm even $m e^{70}$

The reader is left unsure about whether this gossip is true or not. And even if we believe it to be true, this alone still does not mean that she was hypersexual, but just that she had many lovers. We need to consider her

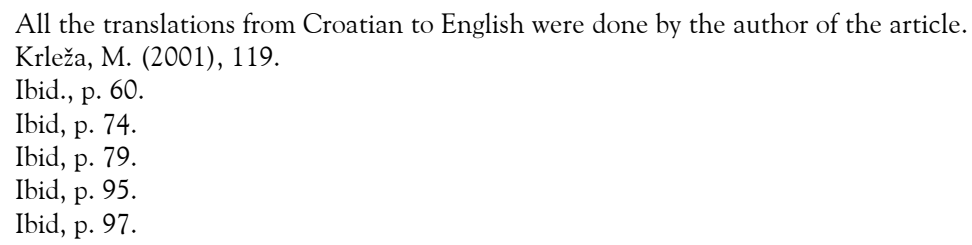


motives for such behaviour and her ability to control her urges to conclude that such behaviour is part of a hypersexuality disorder. On the other hand, Leone tells us (and she confirms) that she had three lovers plus her husband (with whom she had sexual relations at the time) plus Leone, at the same time. Leone said this during a fight with his father, so he could have lied just to hurt him. Nevertheless, Charlotta listens to the quarrel, and later when discussing this with Leone, she never denies it. This can give us a clue to her sexual behaviour, i.e., having five sexual partners who satisfied somewhat different motives - financial (her husband), love and intimacy (Leone), and some other motives that were not mentioned in the play. At the time when she was married to Leone's father, she had been financially secured, and these lovers were less wealthy, less influential and of a lower socioeconomic status than she was, so motives must have been somewhat different to her motives for sexual partners at her younger age, when she had lived a much poorer life. Krleža produces an image of a woman who has unsatisfiable sexual urges, a woman who devours men and continues finding new ones. It is the image of a person with such a huge sexual desire, which cannot be satisfied, that does not look for love or intimacy, close relationships, but just for men as sexual objects. She behaved very much like a person with the hypersexual disorder would do - a repetitive engagement in sexual activities for reasons other than sexual needs; these might be boredom, irritability, anxiety, depression or some other intolerable or frustrating emotion.

The next question is whether she is able to control her sexual desire. We know that her first husband (baron Castelli) divorced after he had found out that she had been cheating on him. Despite losing her money and position, she continues the same behaviour in her second marriage. She says, "I have never been able to protect myself from this physical power that lies in my body", and continues saying that "I am weak by nature", "I cannot restrain my sexual urge, but just let it go". ${ }^{71}$ In these words, we can recognise that she did not have control over her sexual drives. She did not have enough control to suppress these urges, to transfer them into some other activities, but had to release them, to surrender to the drive. Krleža also says that all the money, all the clothes, perfumes, horses, and luxury were not enough to suppress her inner personal drive. All of this gives us enough information to conclude that her behaviour was out of control, which leads to one more criterion met for diagnosing hypersexuality (or out-of-control sexual behaviour, as it is sometimes called).

$71 \quad$ Ibid., p. 122. 
It is also interesting to note that she claimed that only once in her life her sexual engagement was different, and that was when she was in love with Leone. At that time, she "for the first and for the last time lost herself, for the first time she forgot the ordinary, the sensual, and she experienced something non-material, transcendental". ${ }^{72}$ She describes two types of sexual relations with men - one that is sexually driven, physical, sensual; and the other - that is non-physical, non-sensual, but different. It seems that she can distinguish between this uncontrollable sexual urge (compulsive sexual behaviour) and her non-material need for intimacy and love.

She calls her condition "an organic inadequacy", while Leone calls it "an erotic intelligence".

It seems that she was not able to control and suppress her extreme sexual needs and drives that produced negative consequences (both financial and emotional). Charlotta is a fatal woman who destroys men and the male world. ${ }^{73}$

For all these reasons, we can conclude that there is enough information in the play to assess her sexuality as uncontrollable, with negative consequences, motivated by other motives but love and intimacy and therefore, a sign of a disorder, of a condition, a hypersexuality disorder. Oklopčić, in her essay on Charlotta Castelli-Glembay, although starting from a different point of view, concludes that she was a nymphomaniac, which is still another name for the hypersexual disorder. ${ }^{74}$ Similarly, Gašparović claims that the character of baroness is expanded to "monstruous dimensions of uncontrollable, devouring nymphomania". ${ }^{75,76}$

The arguments against hypersexual disorder are that sex was a way for Baroness Castelli Glembay to get money and good life (she confirms that her marriage with Glembay was a financial transaction), and she says that she enjoyed sex. However, once she married Glembay, there was no need to have wealthy lovers any more, as he produced for her all she wanted (during the

\footnotetext{
Ibid., p. 121.

Soldo, Dolores (2013), Koncepcija žene u drami Gospoda Glembajevi Miroslava Krleže (diplomski rad), Filozofski fakultet, Sveučilište u Zagrebu.

74 Oklopčić, Biljana (2008), Stereotipija u prikazu ženskoga lika u genealoškim ciklusima Williama Faulknera i Miroslava Krleže: Eula Varner Snopes i Charlotta Castelli-Glembay, Fluminensia, 20 (1), 99.

75 Gašparović, Darko (1977), Dramatica Krležiana, Zagreb; Prolog.

76 Gredelj, Tihana (2017), Koncepcija žene u Krležinim dramama (diplomski rad), Zagreb; Filozofski fakultet Sveučilišta u Zagrebu, Odsjek za kroatistiku.
} 
quarrel between Leone and his father we realise that he bought her a threestory house in Vienna and that he satisfied every whim she had).

In the final scene, when Leone and the baroness are discussing the quarrel Leone had with his father a night before, Charlotta is trying to explain her behaviour from her stand. However, Leone concludes that he believed her when he was 22, but now he does not believe any of her words. This kind of discourse once again depicts Charlotta as a woman obsessed with sex, a woman one cannot believe, a woman of ill character and moral attitude. Charlotta becomes the stereotype of a fallen woman (a whore), while Angelika is a stereotype or symbol of a saint; one possesses erotic intelligence (and sex is related to evil and immorality) and the other one moral intelligence. ${ }^{77,78}$ Such stereotypical and misogynistic attitudes towards main female characters are not unique to Krleža but are also present in other contemporaneous authors, like William Faulkner (for example, Eula Varner Snopes). ${ }^{79,80}$

Krleža wrote three plays and a dozen prose texts that are considered to form the Glembay cycle. All these texts, as Vidan explains ${ }^{81}$, talk about the loss of moral control, mental illnesses, criminal behaviour and suicide. The Glembays are the prototypes of immorality, mental decadence, and madness. ${ }^{82}$

Even if it is possible to conclude with a high level of certainty that Charlotta was suffering from hypersexuality disorder, fiction cannot provide us with definite diagnoses - after all, fiction is fiction. Nevertheless, attempting such a diagnosis in literary criticism shows the educational value of using a fictional story to teach future mental health (and sexual health) professionals. While other authors (e.g., Oklopčić, Gapšarević, Vidan, Gjurgjan) have described the literary function of fictionalised medicine in Krleža's Messrs. Glembay, our intention here was to demonstrate the medical function of fictionalised medicine, that is, to communicate knowledge of hypersexuality and to use the text for propaedeutic purposes, as literature can improve understanding

Suvin, Darko (1981), Pristup agenskoj strukturi Krležine dramaturgije, Forum, 7-8, 64.

Gašparović, D. (1977).

Oklopčić, B. (2008), 99.

Faulkner, William, (1956). The Hamlet, New York; Vintage Books.

Vidan, Ivo (1975), Tekstovi u kontekstu: odjeci i odnosi u novijoj književnosti, Zagreb; Liber.

Gjurgjan, Lj. (2003), 55. 
of diseases and improve medical education..$^{83,84,85}$ Additionally, fictionalised medicine helps to give a broader picture of medical conditions by adding sociocultural or psychosocial context to the understanding of the condition, which is referred to as the genuine function of the literary descriptions of medical states. ${ }^{86}$

It is also interesting to mention that the sexual drive of baroness Glembay is one of the main themes of the play, while at the same time, the information that her husband Glembay had 27 women in his life did not bother anybody. This information is given by Glembay himself during the fight with his son, but Leone did not comment on this, nor was it mentioned again in the play. This is the reflection of the double-gender standards regarding sexuality at the beginning of the $20^{\text {th }}$ century. But also, it is interesting that no author has considered this fact in medical or literary literature, leading us to the conclusion that even today, in contemporary Croatia, these gender stereotypes are still different for men and women.

In considering other characters, apart from Charlotta, it is interesting to note that Leone is punishing his father for the death of his mother through all three acts of the play. ${ }^{87}$ Leone has Oedipal feelings toward his mother and (almost directly) kills his father and sleeps with his surrogate mother (stepmother). ${ }^{88,89}$ Of course, there exist other explanations of Leone's behaviour, except psychiatric and psychoanalytical, and some of these interpretations include ethical and social elements. ${ }^{90}$

Some of the possible reasons why Charlotta openly exhibited her sexuality, contrary to other women of her time and social status, are: her childhood in poverty, the marginalisation of her mother and lack of a father's figure, and the patriarchal and misogynous society that gives women only a binary possibility to be either a slut or a saint. ${ }^{91}$ The only possibility for the author, because of her (sinful) sexuality, was to kill her in the end.

83 Trautmann, Joanne (1978), The wonders of literature in medical education, in: Donnie J. Self ed., The role of the humanities in medical education: Norfolk: Teagle and Little, 1978, 32.

84 Charon, Rita, Banks, Joanne T., Connelly, Julia E., Hawkins, Anne H., Hunter, Kathryn M., Jones, Anne H., Montello, Martha, Poirer, Suzanne (1995), Literature and medicine: a contribution to clinical practice, Annals of Internal Medicine, 122, 599.

85 Voss, H. (2012), 994.

86 Ibid., p. 994.

87 Klajn, Hugo (1968), Gospoda Glembajevi u svetlu dubinske psihologije, Forum, 1, 103.

88 Ibid., 103.

89 Arbanas, G., Kreho, D. (2019), 40.

90 Stamać, Ante (1993), Što Dubravko Jelačić Bužimski duguje Miroslavu Krleži, Osječki dani, 135.

91 Oklopčić, B. (2008), 99. 


\section{Conclusion}

Hypersexuality disorder (the term from DSM-5) or compulsive sexual behaviour disorder (the term from ICD-II) is a controversial condition that has gotten its place in contemporary medical diagnostic manualsonly in the last decade.

The Croatian author Miroslav Krleža described a woman who, when analysed according to contemporary diagnostic criteria, could be diagnosed (with limited information we have, since there is no way of collecting additional personal history data in a fictional character) with a compulsive sexual behaviour disorder. Interestingly, the author concludes (saying this through the words of Charlotta herself) that the condition is of an organic origin and gives it an interesting name - erotic intelligence.

Medical (psychiatric, sexological) analysis of a piece of literature and its characters can be used in the education of future physicians and/or sexual therapists, and sexologists to give them an insight into the analysis of criteria and differential diagnosis, but also to reflect on personal attitudes and emotions produced by the character and the relationship between the patient and the doctor.

\section{COMPLIANCE WITH ETHICAL STANDARDS}

No conflict of interest exists.

This article does not contain any studies with human participants performed by the author. 


\section{LITERATURE}

1. Andrew, Larner (2005), The Neurology of Alice, Advances in Clinical Neurosciences \& Rehabilitation, 4 (6), 35.

2. Arbanas, Goran (2011), Seksualna ovisnost, Alcoholism, 47, 285.

3. Arbanas, Goran, Kreho, Dinko (2019), Leone Glembay - psihijatrijska i forenzička razmatranja književnog lika, Liječnički Vjesnik, 141, 40.

4. Bancroft, John, Vukadinovic, Zoran (2004), Sexual addiction, sexual compulsivity, sexual impulsivity, or what? Toward a theoretical model. Journal for Sex Research, 43(3), 225.

5. Bostwick, Michael J., Bucci, Jeffrey A. (2008), Internet sex addiction treated with naltrexone, Mayo Clinical Proceedings, 83(2), 226.

6. Bothe, Beatrice, Toth-Kiraly, Istvan, Potenza, Mark, Griffiths, Mark, Orosz, Gabor, Demetrovics, Zsolt (2018), Revisiting the role of impulsivity and compulsivity in problematic sexual behaviours, Journal of Sex Research, 18, 1.

7. Bronte, Charlotte (1847). Jane Erye, New York; Black \& White Classics.

8. Carnes, Patric, Schneider, Jennifer P. (2000), Recognition and management of addictive sexual disorders: guide for the primary care clinician, Lippincotts Primary Care Practice, 4 (3), 302.

9. Carroll, Lewis (1998). Alice's Adventures in Wonderland, London; Penguin Classics.

10. Carvalho, Joana, Stulhofer, Aleksandar, Vieira, Armando L., Jurin, Tanja (2015), Hypersexuality and high sexual desire: exploring the structure of problematic sexuality, Journal of Sexual Medicine, 12, 1356.

11. Charon, Rita, Banks, Joanne T., Connelly, Julia E., Hawkins, Anne H., Hunter, Kathryn M., Jones, Anne H., Montello, Martha, Poirer, Suzanna (1995), Literature and medicine: contributions to clinical practice, Annals of Internal Medicine, 122, 599.

12. Charpy, Jean-Pierre (2014), Medical thrillers: doctored fiction for future doctors? Journal of Medical Humanities, 35, 423.

13. Coon, Elizabeth A., Hassan, Anhar (2015), Did the 'Woman in the Attic' in Jane Eyre have Huntington disease? Tremor $\mathcal{E}$ Other Hyperkinetic Movements, 21(5), 323.

14. Diagnostic and statistical manual of mental disorders, fifth edition American Psychiatric Association(2013), Arlington: American Psychiatric Association.

15. Diagnostic and statistical manual of mental disorders, $3^{\text {rd }}$ edition revised American Psychiatric Association (1987), Arlington: American Psychiatric Association.

16. Dostoevsky, Fyodor M. (1992). The Idiot, Oxford and New York; Oxford University Press, 485.

17. Faulkner, William (1956). The Hamlet, New York; Vintage Books.

18. Garcisa, Frederico D., Thibaut, Florence (2010), Sexual addictions, American Journal of Drug Alcohol Abuse, 36(5), 254.

19. Gašparović, Darko (1977). Dramatica Krležiana, Zagreb; Prolog.

20. Gjurgjan, Ljiljana I. (2003), Fetišizam, vampirizam i pogled drugoga u drami Gospoda Glembajevi Miroslava Krleže, Dani hrvatskoga kazališt: Građa i rasprave o hrvatskoj književnosti i kazalištu, 29 (2), 55.

21. Gredelj, Tihana (2017), Koncepcija žene u Krležinim dramama (diplomski rad), Zagreb; Filozofski fakultet Sveučilišta u Zagrebu, Odsjek za kroatistiku. 
22. Haan, Joost, Koehler, Peter J. (2014), Traces of hysteria in novels, Frontiers in Neurology \& Neuroscience, 35, 99.

23. Holden, Constance (2001), Behavioral addictions: do they exist? Science, 294, 980.

24. Huntington, George (1872), On chorea, The Medical and Surgical Reporter, 16, 317.

25. The ICD-10 classification of mental and behavioural disorders: clinical descriptions and diagnostic guidelinesWorld Health Organization (1992), Geneve: World Health Organization.

26. Jukić, Vlado, Brečić, Petrana, Savic, Aleksandar (2010), Movies in education of psychiatry residents, Psychiatria Danubina, 22(2), 304.

27. Kafka, Martin P. (2010a), What is sexual addiction? A response to Stephen Levine, Journal of Sex and Marital Therapy, 36, 276.

28. Kafka, Martin P. (2010b), Hypersexual disorder: a proposed diagnosis for DSM-V, Archives of Sexual Behavior, 39(2), 377.

29. Kafka, Martin P., Prentky, Robert (1992), Fluoxetine treatment of nonparaphilic sexual addictions and paraphilias in men, Journal of Clinal Psychiatry, 53(10), 351.

30. Karila, Laurent, Wery, Aline, Weinsten, Aviv, Cottencin, Olivier, Petit, Aymeric, Reynaud, Michel, Billieux, Joel (2014), Sexual addiction or hypersexual disorder: different terms for the same problem? A review of the literature, Current Pharmacological Design, 20(25), 4012.

31. Khazaal, Yasser, Zullino, Daniele F. (2006), Topiramate in the treatment of compulsive sexual behaviour: case report, BMC Psychiatry, 6, 22.

32. Kingston, Drew A. (2018), Hypresexuality: fact or fiction? Journal of Sexual Medicine, 15, 613 .

33. Klajn, Hugo (1968), Gospoda Glembajevi u svetlu dubinske psihologije, Forum, 1, 103.

34. Krleža, Miroslav (2001). Gospoda Glembajevi, Zagreb; Naklada Ljevak.

35. Langstrom, Niklas, Hanson, Karl R. (2006), High rates of sexual behaviour in the general population: correlates and predictors, Archives of Sexual Behavior, 35(1), 37.

36. Levine, Stephen B. (2010), What is sexual addiction?, Journal of Sex and Marital Therapy, 36, 261.

37. Lukašević, Tatjana S. (2013), Samostanske drame i Glembajevi, Croatica Slavica Iadertina, 9 (2), 433.

38. Maxwell, Marilyn (2011), A study in contrasts: inscriptions of posttraumatic stress disorder (PTSD) in two works of fiction, Work, 38, 19.

39. McEwan, Ian (2005). Saturday, London; Vintage.

40. Mick, Thomas M., Hollander, Eric (2006), Impulsive-compulsive sexual behaviour, CNS Spectrums, 11(12), 944.

41. Novak, Slobodan P. (2004). Povijest hrvatske knjižernosti, Split; Marijan tisak.

42. Oklopčić, Biljana (2008), Stereotipija u prikazu ženskoga lika u genealoškim ciklusima Williama Faulknera i Miroslava Krleže: Eula Varner Snopes i Charlotta Castelli-Glembay, Fluminensia, 20(1), 99.

43. Orzack, Maressa H., Voluse, Andrew C., Wolf, David, Hennen, John (2006), An ongoing study of group treatment for men involved in problematic Internet-enabled sexual behaviour, Cyberpsychology \& Behavior, 9(3), 348.

44. Sawyer, Robert J. (1997). Frameshift, New York; Tom Doherty Associates, 99. 
45. Seegers, Jennifer A. (2003), The prevalence of sexual addiction symptoms on the college campus, Sexual Addiction \& Compulsivity, 10, 247.

46. Slunjski, Kristina (2015), Alice u Zemlji Čudesa kao susretište književnosti i medicine i kao poticaj medicinskom nazivlju, Libri $\mathcal{E}$ Liberi, 4(2), 341.

47. Soldo, Dolores (2013), Koncepcija žene u drami Gospoda Glembajevi Miroslava Krleže, (diplomski rad), Zagreb: Filozofski fakultet, Sveučilište u Zagrebu.

48. Stamać, Ante (1993), Što Dubravko Jelačić Bužimski duguje Miroslavu Krleži, Osječki dani, 135.

49. Stein, Don J. (2008), Classifying hypersexual disorders: compulsive, impulsive, and addictive models, The Psychiatric Clinics of North America, 31(4), 587.

50. Suvin, Darko (1981), Pristup agenskoj strukturi Krležine dramaturgije, Forum, 7-8, 64.

51. Trautmann, Joanne (1978), The wonders of literature in medical education, in: Donnie J. Self ed., The role of the Humanities in medical education: Norfolk: Teagle and Little. 1978, 32.

52. Vidan, Ivo (1975). Tekstovi u kontekstu: odjeci i odnosi u novijoj knjižernosti, Zagreb; Liber.

53. Vonnegut, Kurt (1985). Galapagos, New York; Delacorte Press/Seymour Lawrence, 85.

54. Voss, Hendrik (2012), The representation of movement disorders in fictional literature, Journal of Neurology, Neurosurgery and Psychiatry, 83, 994.

55. Weissenstein, Anne, Luchter, Elisabeth, Bittmann, Stefan M.A. (2014), Alice in Wonderland syndrome: a rare neurological manifestation with microscopy in a 6-year-old child, Journal of Pediatric Neurosciences, 9(3), 303.

56. Womack, Stephanie, Hook, Joshua, Ramos, Marciana, Davis, Don, Penberthy, Kim (2013), Measuring hypersexual behaviour Sexual addiction \& compulsivity, Journal of Treatment and Prevention, 20(1-2), 65.

57. Young, Kimberly S. (2007), Cognitive behaviour therapy with Internet addicts: treatment outcomes and implications, Cyberpsychology \& Behavior, 10(5), 671.

58. 6C72 Compulsive sexual behaviour disorder (2020), in: World health organization, International classsification of diseases, https:/icd.who.int/browse11/1-m/en\#/http:// id.who.int/icd/entity/1630268048 


\section{SAŽETAK}

Hiperseksualni poremećaj (seksualna ovisnost, prekomjeran seksualni nagon ili poremećaj s kompulzivnim seksualnim ponašanjem) kontroverzno je stanje koje je prisutno u jednom (Međunarodna klasifikacija bolesti), no ne i u drugom važećem klasifikacijskom sustavu (Dijagnostički i statistički priručnik za duševne poremećaje). Definira se kao klinički sindrom obilježen ustrajnim obrascem nemogućnosti kontrole poriva, opetovanim seksualnim porivima ili nagonima, koji dovode do opetovanih seksualnih ponašanja. Ovo stanje češće je kod muškaraca, nego kod žena.

Neka medicinska stanja opisana su u literaturi prije negoli su formalno prepoznata u medicinskim krugovima, npr. Huntingtonova bolest, Pickwickov sindrom i Munchausenov sindrom.

Cilj je ovog rada bio analizirati lik barunice Charlotte Castelli Glembay iz Gospode Glembayevih Miroslava Krleže. Krleža je u ovom djelu opisao ženu sa seksualnim nagonom koji bi se mogao definirati kao nekontroliran, organski (tjelesno) uvjetovan i različit od ljubavi $i$ zaljubljenosti (koju je ona također doživjela, no samo s jednim muškarcem). Krleža je dao $i$ posebno ime za njezino stanje - erotična inteligencija. Konačno, njezino seksualnu ponašanje imalo je uznemirujuće i negativne posljedice. Može se zaključiti da je riječ o opisu hiperseksualnog poremećaja kod žene, uz oznaku njegove etiologije. U skladu s prevladavajućim stavovima toga vremena (početak 20. stoljeća), hiperseksualnost kod žena imala je negativne konotacije.

Ključne riječi: hiperseksualnost, seksualna ovisnost, nekontrolirano seksualno ponašanje, nimfomanija, poremećaj s kompulzivnim seksualnim ponašanjem, Miroslav Krleža, Gospoda Glembayevi 